\title{
O ativismo judicial é um jogo sem fair play? Direito e Brincadeira
}

\author{
Is judicial activism a game without fair play? Law and play \\ ¿Es el activism judicial um juego sin juego limpio? Ley e juego
}

Recebido: 16/02/2021 | Revisado: 21/02/2021 | Aceito: 26/02/2021 | Publicado: 07/03/2021

\author{
Janaina de Castro Marchi Medina \\ ORCID: https://orcid.org/0000-0002-4652-7153 \\ Faculdade FADISP, Brasil \\ E-mail: janainacmm@gmail.com \\ Renata Maria Silveira Toledo \\ ORCID: https://orcid.org/0000-0002-8571-9705 \\ Faculdade FADISP, Brasil \\ Universidade Metodista de São Paulo, Brasil \\ E-mail: renatamariastoledo@gmail.com
}

\begin{abstract}
Resumo
O presente artigo tem por objetivo analisar o fenômeno do ativismo judicial no jogo do Direito, cuja relevância justifica-se pela crise democrática instalada no Brasil. Para tanto, houve a preocupação em se fazer um resgate histórico do seu contexto, a diferenciação entre ativismo judicial e judicialização de políticas públicas, e o enfrentamento de duas posições doutrinárias antagônicas: a de Luís Roberto Barroso e a de Lenio Luiz Streck. O trabalho ainda permeia discussões sobre a vulnerabilidade da democracia e as regras de seu jogo, impactados pela aplicação de um "ativismo" às avessas do Poder Executivo e decisões judiciais ativistas proferidas no momento em que passa por pandemia do COVID-19, fundadas em valores pessoais de seus respectivos representantes institucionais, que atuam como intérpretes constitucionais. A pesquisa utilizou-se da metodologia dedutiva por meio de pesquisa bibliográfica, incluindo autores nacionais e estrangeiros, além de decisões judiciais recentes que demonstram como se está lidando com a atual crise sanitária.
\end{abstract}

Palavras-chave: Direito; Brincadeira; Jogo; Ativismo judicial; Judiacialização; Pandemia; COVID-19.

\begin{abstract}
This article aims to analyze the phenomenon of judicial activism in the game of Law, whose relevance is justified by the democratic crisis installed in Brazil. Therefore, therefore was a concern to make a historical recovery of its context, the differentiation between judicial activism and the judicialization of public policies, and the confrontation of two antagonistic doctrinal positions: Luís Roberto Barroso and Lenio Luiz Streck. The work still permeates discussions about the vulnerability of democracy and its rules game, impacted by the application of an "activism" to the inside of the Executive Power and activist judicial decisions handed down when it is going through a COVID-19 pandemic, based on values personal of their respective institutional representatives, who act as constitutional interpreters. The research used the deductive methodology through bibliographic research, including national and foreign authors, in addition to recent judicial decisions that demonstrate how the current health crisis is being dealt with.
\end{abstract}

Keywords: Right; Play; Game; Judicial activism; Judicialization; Pandemia; COVID-19.

\section{Resumem}

Este artículo tiene como objetivo analizar el fenómeno del activismo judicial en el juego de la Ley, cuya relevancia está justificada por la crisis democrática instalada en Brasil. Por eso, se preocupó por hacer un rescate histórico de su contexto, la diferenciación entre activismo judicial y judicialización de políticas públicas, y el enfrentamiento de dos posiciones doctrinales opuestas: la de Luís Roberto Barroso y la de Lenio Luiz Streck. La obra aún permea discusiones sobre la vulnerabilidad de la democracia y las reglas de su juego, impactadas por la aplicación de un "activismo" al interior del Poder Ejecutivo y decisiones judiciales activistas dictadas cuando atraviesa una pandemia de COVID-19, basada en valores. datos personales de sus respectivos representantes institucionales, quienes actúan como intérpretes constitucionales. La investigación utilizó la metodología deductiva a través de investigaciones bibliográficas, incluyendo autores nacionales y extranjeros, además de recientes decisiones judiciales que demuestran cómo se está afrontando la actual crisis de salud.

Palabras clave: Derecho; Broma; Juego; Activismo judicial; Judicialización; Pandemia; COVID-19. 


\section{Introdução}

Desde que foi pensada ou inventada na Grécia antiga e aprimorada pelos séculos até os dias de hoje, para ser considerada a melhor forma de governo que se conhece, a democracia passa por várias crises, mais simples ou mais complexas. Considerando também os regimes autoritários da Europa que duraram até o século passado e as ditaduras que vez por outra ameaçam os regimes, colocam-se os estudiosos a tentar entender as regras do jogo democrático e a tentar, ao mesmo tempo, jogar com as regras de que dispõem.

Muitos fatores podem levar à fragilização ou, até, ao colapso da democracia. Neste trabalho voltamos a atenção para um fenômeno que muito tem preocupado estudiosos do direito (e também de outras áreas do conhecimento), que é o ativismo judicial. O tema tem sido objeto de discussões na área jurídica e, também, na política e economia, no Brasil e no exterior.

O ativismo é um termo de muitos significados, podendo ser visto como algo positivo ou negativo, a depender da concepção de ativismo que se adote (ou, até, da "ideologia" ativista que se defende). No presente estudo nos propomos a analisar os posicionamentos antagônicos de dois juristas, Luís Roberto Barroso e Lenio luiz Streck. Realizaremos esta análise confrontando acontecimentos recentes que se relacionam com ativismo judicial e com a judicialização. Uma diferenciação entre esses dois fenômenos - judicialização e ativismo judicial - deve ser apresentada, a fim de se compreender o contexto em que se manifesta a realidade jurídica brasileira.

A necessária superação do dualismo entre a teoria e a prática conduz à questão sobre qual o "entendimento" ou interpretação correta das normas constitucionais (seja num tribunal, numa câmara legislativa ou em um órgão administrativo), sem, contudo, jogar para enfraquecer o outro poder, ou mesmo transformar a função que se exerce numa artimanha políticopessoal, que pode resultar numa subversão "legal" do modo como os órgãos se relacionam, num jogo sem "fair play".

Vive-se, hoje, uma crise histórica sem precedentes, gerada, em grande medida, pela pandemia da COVID-19, uma epidemia viral de escala mundial com consequências catastróficas, que ainda não chegou ao seu final. Nesse contexto, analisaremos algumas decisões judiciais proferidas com o propósito de trazer solução à crise de saúde, a fim de verificar se elas são, ou não, manifestação de ativismo judicial.

\section{Metodologia}

O método de organização do conhecimento jurídico e a consequente reflexão do assunto foi contextualizado de março a dezembro de 2020, com o desafio de tratar do tema "ativismo" no mesmo momento em que aconteciam lockdowns, tentavase entender biológica e sanitariamente o que seria o coronavírus e, deste modo, analisar juridicamente o que se estava passando socialmente e institucionalmente.

No estudo do direito encontram-se, ao menos, dois enfoques distintos, em se tratando de métodos: um primeiro que trata da teoria geral do direito, voltado ao conhecimento e explicação do fenômeno jurídico; e uma segunda, que lida com a constituição de uma dogmática do direito, tendo como objeto a análise de apreciação judicial de casos e a solução de questões jurídicas (Abboud, 2015).

$\mathrm{O}$ artigo aborda discussões sobre a fragilidade dos regimes democráticos e as regras com que governantes e magistrados jogam, seja pela aplicação de um "ativismo" às avessas do Poder Executivo, ou seja, por decisões judiciais ativistas proferidas, em especial, neste momento em que passa por pandemia do COVID-19. Tais políticas ou decisões podem ser fundadas em valores pessoais de seus respectivos representantes institucionais, ao tempo em que atuam como intérpretes constitucionais.

Esta pesquisa utilizou-se da metodologia qualitativa de análise, por meio de pesquisa bibliográfica, incluindo autores nacionais e estrangeiros. Para tanto, no estudo do direito, além da análise qualitativa de decisões judiciais e a análise 
normativa, busca-se contextualizar dentro da problemática jurídica a decisão judicial ou a regra legislativa ou administrativa à luz dos acontecimentos ou fatos que estamos presenciando, e se tal entendimento está auxiliando ou não no enfrentamento da atual crise sanitária.

\section{Direito, Jogo e Brincadeira}

A noção do direito é permeada pelo jogo e as construções sociais são criadas com base nas noções de jogo.

Huizinga (2012) defende que o jogo é um fenômeno cultural e a base da civilização e, estas regras são um fator muito importante para o conceito de jogo. Todo jogo tem suas regras. São estas que determinam aquilo que "vale" dentro do mundo temporário por ele circunscrito. O autor passa a traçar um paralelo entre o jogo e as cerimônias religiosas, esclarecendo que todo o sistema de crenças e práticas (rituais) não foi inventado à toa, mas busca uma evolução de um grupo específico e representam um jogo, $\mathrm{O}$ autor também estabelece uma relação de afinidade entre o jogo e a competição, e conclui:

O jogo é um combate e o combate é um jogo. Porém, o que parece mais relevante é a aproximação que o autor faz entre o jogo e a música: A interpretação musical possui desde o início todas as características formais do jogo propriamente dito. É uma atividade que se inicia e termina dentro de estreitos limites de tempo e de lugar, é passível de repetição, consiste essencialmente em ordem, ritmo e alternância, transporta tanto o público como os intérpretes para fora da vida quotidiana, para uma região de alegria e serenidade, conferindo mesmo à música triste o caráter de um sublime prazer.

Huizinga (2012) ainda inclui a competição na categoria de jogo, ambos desprovidos de objetivos “extra partes”. O que os competidores ou jogadores buscam é o prazer do êxito. E pondera:

A ideia de ganhar está estreitamente relacionada com o jogo. Todavia, para alguém ganhar é preciso que haja um parceiro ou adversário; no jogo solitário não se pode realmente ganhar, não é este o termo que pode ser usado quando o jogador atinge o objetivo desejado. O que é 'ganhar', e o que é que realmente 'ganho'? Ganhar significa manifestar sua superioridade num determinado jogo. Contudo, a prova desta superioridade tem tendência para conferir ao vencedor uma aparência de superioridade em geral. Ele ganha alguma coisa mais do que apenas o jogo enquanto tal. Ganha estima, conquista honrarias: e estas honrarias e estima imediatamente concorrem para o benefício do grupo ao qual o vencedor pertence. O que é primordial é o desejo de ser melhor que os outros, de ser o primeiro e ser festejado por esse fato. Só secundariamente tem importância o fato de resultar da vitória um aumento do poder do indivíduo ou do grupo. O principal é ganhar.

Na obra Homo Ludens, Huizinga (2012) passa a dissertar sobre a relação entre Direito e Jogo propriamente dita, e esclarece que o elemento "lúdico" do jogo não descaracteriza a seriedade do Direito.

Assim, se o Direito é um jogo, os elementos desse jogo são as estruturas do Direito e estudá-las é importante para sabermos, previamente, como devemos jogar esse jogo. Não respeitadas as estruturas do jogo, o Direito é aniquilado, porque ele perde sua narrativa.

A partir desta ideia de que o Direito é um jogo, a pergunta que se faz é: quais são usuas regras?

Foucault (2017), ao se dedicar ao estudo da fala franca, ensina que "parresia" é uma modalidade de dizer-a-verdade, e a forma como o sujeito se manifesta dizendo a verdade o constitui e continua:

Porque se o parresiasta é de fato aquele que assume o risco de questionar sua relação com o outro e até sua própria existência dizendo a verdade, toda a verdade, contra todos e contra tudo, por outro lado, aquele a quem essa verdade é dita - quer se trate do povo reunido e que delibera sobre as melhores decisões a tomar, quer se trate do Príncipe, do tirano ou do rei a que é preciso dar conselhos, quer se trate do amigo que você guia -, este (povo, rei, amigo) se quiser desempenhar o papel que lhe propõe o parresiasta dizendo-lhe a verdade (deve) aceitá-la, por mais desagradáveis que sejam para as opiniões estabelecidas na Assembleia, para as paixões ou os interesses do Príncipe, para a ignorância ou 
a cegueira do indivíduo. O povo, o Príncipe, o indivíduo devem aceitar o jogo da parresia. Devem eles próprios jogalo e reconhecer que aquele que assume o risco de lhes dizer a verdade deve ser escutado. E é assim que se estabelecerá o verdadeiro jogo da parresia, a partir dessa espécie de pacto que faz que, se o parresiasta mostra sua coragem dizendo a verdade contra tudo e contra todos, aquele a que essa parresia é endereçada deverá mostrar sua grandeza de alma aceitando que lhe digam a verdade. Essa espécie de pacto, entre aquele que assume o risco de dizer a verdade e aquele que aceita ouvi-la, está no cerne do que se poderia chamar de jogo parresiástico.

Assim, o Direito é um jogo, com rituais, procedimentos, narrativa próprios, cujas regras precisam ser a do "jogo parresiástico". A pergunta que se faz é: o que é o ativismo judicial no jogo do Direito, o que está por trás desse conceito e qual o impacto para a nossa sociedade?

\section{O Ativismo Judicial}

\subsection{Um breve resgate histórico do ativismo judicial}

Não há, na doutrina, uniformidade sobre o que pode ser considerado ativismo judicial. Por exemplo, para alguns, as decisões tomadas pelas cortes constitucionais com o propósito de concretizar direitos fundamentais seriam exemplos de ativismo judicial realizado em conformidade com a constituição. Assim, por exemplo, escreveu o professor José Afonso da Silva (2013):

(...) ativismo judicial consiste na interpretação constitucional criativa, que pode chegar até à constitucionalização de direitos, pelo que se pode dizer que se trata de uma forma especial de interpretação construtiva. É por essa forma de interpretação criativa que os Tribunais Constitucionais europeus e a Corte Suprema dos Estados Unidos têm produzido constitucionalizações de direitos enriquecedoras da democracia. As Cortes Constitucionais da Espanha, da Itália e da Alemanha são baluartes da vigência e eficácia dos direitos fundamentais em seus países. Mas não é o caso de descer a pormenores aqui. Basta lembrar dois exemplos de constitucionalização de direitos que demonstram quanto à interpretação criativa é capaz de penetrar no âmago da Constituição para de seu contexto revelar o mais fundo significado, para além do seu conteúdo manifesto, sem, no entanto, ultrapassar os limites que sua pauta de valor circunscreve. Refiro-me a atuação da Corte Suprema dos Estados Unidos, especialmente pela destacada atuação do Chief Justice Warren e do Chief Justice Burger que desenvolveu a doutrina do devido processo legal substantivo, com base na qual foram constitucionalizados direitos substantivos, como, entre tantos, o direito à intimidade, não expressamente previsto na Constituição. Assim também a atuação do Conselho Constitucional da França pela qual se construiu 'bloco de constitucionalidade' fértil na criação de direitos. São exemplos de um ativismo judicial no melhor sentido, com o qual se operou profunda revolução social (pp.8-9).

O professor Silva (2013) distingue esse ativismo judicial, que seria considerado uma prática adequada à constituição, do que ele chama de "abuso no exercício da função jurisdicional" e prossegue:

Abuso no exercício da função jurisdicional é tão inconstitucional como o abuso das funções executiva e legislativa, tipo de interpretação que Umberto Eco chama de 'superinterpretação', pela qual se exerce um ativismo judicial exacerbado (p.9)

De fato, Eco (2018), em seu livro “Os limites da Interpretação”, assim afirma:

Mas o texto é um organismo, um sistema de relações internas que atualiza certas ligações possíveis e narcotiza outras. Antes que um texto seja produzido, seria possível inventar qualquer espécie de texto. Depois que um texto foi produzido, é possível faze-lo dizer muitas coisas - em certos casos um número potencialmente infinito de coisas - mas é impossível - ou pelo menos ilegítimo - faze-lo dizer o que não diz (p.81).

Prossegue Silva (2013), afirmando que: 
Não se trata, em tais casos, de ativismo judicial, mas de abuso. O abuso de direito, o abuso de funções como o abuso de poder é sempre condenado. Os magistrados, por exercerem uma função de solução de controvérsias pela qual reconhecem direitos a uns e os negam a outros, precisam ser muito ponderados, muito sóbrios, para que possam ser justos. Um Tribunal Supremo, como o STF, de modo especial, tem que exercer sua magistratura ainda com maior atenção e sobriedade, porque, sendo supremo, não há quem possa corrigir suas decisões menos ponderadas. No entanto, não raro, o Tribunal, ou pelo menos alguns de seus ministros, parecem imbuídos de que detêm um super poder acima do bem e do mal, com posturas que a Constituição não lhes reconhece, e o pior, muitas vezes praticadas com arrogância, o que não é próprio de um Tribunal constitucional. O governo dos juízes é tão danoso quanto a ditadura do Executivo (p.10).

Por ser o ativismo judicial um termo polissêmico, muitos autores usam a expressão com outro propósito, para designar algo mais restrito. Muitos consideram haver ativismo em casos em que se cria algo novo, não previsto na Constituição. Segundo Medina (2020), isso pode ocorrer, por exemplo, quando 1) o Supremo Tribunal Federal criminaliza condutas, 2) cria princípios ou direitos fundamentais que não existem na constituição, e 3) além de criar princípios, "pondera" valores que não guardam correspondência entre si.

O Supremo Tribunal Federal admite que o ativismo judicial é justificável em determinados contextos, e, em tempos recentes, tem incorporado cada vez mais essa prática. Essa tendência que foi expressamente manifestada, p.ex., no julgamento da ADIn 4.277, no qual se reconheceu a união homoafetiva como entidade familiar: "Práticas de ativismo judicial, embora moderadamente desempenhadas pela Corte Suprema em momentos excepcionais, tornam-se uma necessidade institucional, quando os órgãos do Poder Público se omitem ou retardam, excessivamente, o cumprimento de obrigações a que estão sujeitos” (STF, ADIn 4.277, j. 05.05.2011, voto do Min. Celso de Mello, item IX, p. 46).

Vê-se que o ativismo judicial, nos termos sugeridos no trecho acima transcrito, pressupõe o reconhecimento de que os demais órgãos do Estado (chamados de "poderes" pela Constituição Federal) deixam, injustificavelmente, de atuar, seja ao se omitirem quanto à edição de leis que permitam a fruição de direitos fundamentais, seja ao se omitirem na prática de atos de administração ou de gestão dos bens públicos que viabilizem a concretização de tais direitos. Nessas circunstâncias, o Supremo Tribunal Federal passa a desempenhar o controle de constitucionalidade de forma proativa, não mais se limitando, p.ex., a declarar a constitucionalidade ou inconstitucionalidade de um enunciado elaborado pelo Poder Legislativo.

Nesse contexto, a prática do ativismo judicial joga com as regras de qualquer estado democrático, que se pauta minimamente por convivência razoavelmente harmônica entre os órgãos (ou poderes) do estado. Espera-se que cada um deles ocupem seus espaços sem interferirem nos dos outros, em consonância com suas competências estabelecidas na Constituição Federal. O ativismo judicial, diante disso, é excepcional.

Em tempos recentes, os estudiosos vêm fazendo referência a modos e formas diversificadas de violação à Constituição Federal, que sucedem quanto agentes estatais realizam atividades aparentemente conforme à Constituição e às leis, mas que, na verdade, acabam tendo por consequência (ou, até, propósito) a mitigação de direitos fundamentais ou de outros valores essenciais do Estado constitucional. No Estado que se pretende Democrático e de Direito, no Estado Constitucional, quando um dos poderes atua de modo abusivo no exercício de suas competências, que colocam em risco a própria existência do sistema, há natural reação de alguns ou de todos os demais sujeitos (jogadores?) do cenário político e constitucional. Com isso, o órgão provocado expande seu âmbito de atuação, com o propósito de conter a prática abusiva do outro.

Medina (2020), com base na doutrina de Kim Lane Scheppele, alude a uma prática que denomina de legalismo autocrático, que pode ser resumida do seguinte modo:

(...) o manejo de instrumentos legais por aquele que comanda o Executivo com o propósito (explícito ou implícito) de ampliar seu próprio poder de atuação, restringindo meios de controle público acerca de seus atos e limitando direitos básicos inerentes à democracia (p. 486) 
O legalismo autocrático é uma das formas de manifestação do constitucionalismo abusivo. O tema foi objeto de decisão proferida pelo Ministro Barroso, no STF, na ADPF 622: "Importância de evitar os riscos do constitucionalismo abusivo: prática que promove a interpretação ou a alteração do ordenamento jurídico, de forma a concentrar poderes no Chefe do Executivo e a desabilitar agentes que exercem controle sobre a sua atuação. Instrumento associado, na ordem internacional, ao retrocesso democrático e à violação a direitos fundamentais".

Assim, considerando que o Supremo Tribunal Federal vê o ativismo judicial como forma de extrapolação de seu âmbito de atuação em situações excepcionais, parece correto afirmar que essa expansão jurisdicional acompanha, ainda que de modo não muito preciso, os modos de violação comissiva ou omissiva da ordem constitucional pelos demais agentes estatais. Se, em dado momento histórico, aquele tribunal admite haver ativismo em caso de omissão injustificável quanto à realização de direitos fundamentais (como no caso da decisão sobre reconhecimento de união homoafetiva como entidade familiar, antes referido), parece ser possível considerar que a prática ativista do Supremo tende a ajustar-se a novos modos de violação à Constituição, como na prática de legalismo autocrático, a que acima se referiu.

Observemos, nesse contexto, os pensamentos opostos de Barroso e Streck.

\subsection{Ativismo na visão de Luís Roberto Barroso}

Para defender o ativismo judicial, Barroso (2005) aborda a trajetória e as transformações do direito constitucional pelo viés histórico, filosófico e teórico nas últimas décadas e seu papel na interpretação do direito.

Para o autor, "o marco histórico do novo direito constitucional, na Europa continental, foi o constitucionalismo do pós-guerra, especialmente na Alemanha e na Itália. No Brasil, foi a Constituição de 1988 e o processo de redemocratização que ela ajudou a protagonizar.” E no campo filosófico esclarece:

(...) o jusnaturalismo moderno, desenvolvido a partir do século XVI, aproximou a lei da razão e transformou-se na filosofia natural do Direito" (...) "A superação histórica do jusnaturalismo e o fracasso político do positivismo abriram caminho para um conjunto amplo e ainda inacabado de reflexões acerca do Direito, sua função social e sua interpretação. O pós-positivismo busca ir além da legalidade estrita, mas não despreza o direito posto: procura empreender uma leitura moral do Direito, mas sem recorrer a categorias metafísicas.

E no marco filosófico, o autor, então, defende o ativismo judicial como um método de "interpretação do Direito" enquanto modalidade de interpretação jurídica decorrente da força normativa da Constituição Federal, especialmente de normas que contêm conceitos jurídicos indeterminados, locuções tais como “ordem pública, interesse social e boa-fé" para o que "o intérprete precisa fazer a valoração de fatores objetivos e subjetivos presentes na realidade fática, de modo a definir o sentido e o alcance da norma" e pondera:

A interpretação e aplicação do ordenamento jurídico hão de ser inspiradas por uma teoria de justiça, mas não podem comportar voluntarismos ou personalismos, sobretudo os judiciais. No conjunto de ideias ricas e heterogêneas que procuram abrigo neste paradigma em construção incluem-se a atribuição de normatividade aos princípios e a definição de suas relações com valores e regras; a reabilitação da razão prática e da argumentação jurídica; a formação de uma nova hermenêutica constitucional; e o desenvolvimento de uma teoria dos direitos fundamentais edificada sobre o fundamento da dignidade humana. Nesse ambiente, promove-se uma reaproximação entre o Direito e a filosofia (p.05).

Ao lado do argumento do ativismo como regra de interpretação da Constituição, Barroso (2005) também defende a constitucionalização do direito como fundamento para o ativismo judicial para, grosso modo, limitar a discricionariedade dos Poderes, impor-lhes deveres de atuação para realização de direitos programas constitucionais, limitar a autonomia da vontade 
de particulares subordinada a valores constitucionais e respeito aos direitos fundamentais, e, especialmente quanto ao Poder Judiciário, servir de parâmetro para controle de constitucionalidade e interpretação de todas as normas.

Assim, no texto Neoconstitucionalismo e Constitucionalização do Direito: O triunfo tardio do direito constitucional no Brasil, Barroso (2005) defende que é papel do Poder Judiciário e das Cortes Constitucionais resguardar o processo democrático e promover valores constitucionais, espaço que se abre para o ativismo judicial, que somente constituirá abuso se houver o exercício de "políticas" ao invés da realização dos princípios constitucionais.

Barroso (2012) ainda esclarece que há uma diferença entre ativismo judicial e judicialização, embora tenham a mesma origem, sendo que a judicialização está relacionada ao fato de que ao juiz é dado julgar sempre que uma causa lhe é submetida, não podendo declinar da jurisdição, enquanto o ativismo judicial é um modo de interpretar o Direito de acordo com os valores constitucionais, e pondera:

(...) a judicialização no contexto brasileiro é um fato, uma circunstância que decorre do modelo constitucional que se adotou, e não um exercício deliberado de vontade política. Isso porque a redemocratização do Brasil, especialmente com o advento da abrangente Constituição Federal de 1988 e o nosso sistema de controle de constitucionalidade são as causas da judicialização da política, de forma que esse fenômeno não decorre, em sua visão, de opção ideológica, filosófica ou metodológica da Corte, que estaria apenas cumprindo seu papel constitucional em conformidade com o desenho institucional vigente.

$\mathrm{O}$ autor reconhece que tanto o ativismo judicial quanto a judicilização geram “(...) riscos para a legitimidade democrática, na politização indevida da justiça e nos limites da capacidade institucional do Judiciário."

Acontece que os métodos de interpretação estão relacionados à hermenêutica jurídica, e a "interpretação conforme a constituição" não autoriza a criação de normas. Quanto aos conceitos subjetivos e indeterminados mencionados pelo Autor, tais como boa-fé objetiva, função social, dignidade da pessoa humana constituem cláusulas gerais.

No item seguinte chamaremos a atenção para outros pontos de vista manifestados por Barroso, após sua nomeação como ministro do Supremo Tribunal Federal, confrontando-os com as opiniões de Streck, a respeito.

\subsection{O ativismo na visão de Lenio Luiz Streck}

As considerações a seguir são extraídas de obras e artigos, mas, sobretudo, de textos publicados por Lenio Luiz Sreck na revista eletrônica Consultor Jurídico. Assim procedemos metodologicamente porque nesses textos esse autor manifesta, de modo mais contundente, suas discordâncias em relação às opiniões de Luís Roberto Barroso, marcadamente desde a época da nomeação deste como ministro do Supremo Tribunal Federal.

Segundo Streck (2013a), Barroso acreditava não haver "um surto de ativismo judicial" em curso no país, e a quantidade de leis declaradas inconstitucionais pelo Supremo eram ínfimas. O que anteriormente considerava, agora como ministro já não considera haver tanto ativismo. Ao mesmo tempo, há a defesa de que o Supremo Tribunal Federal deva ser uma "vanguarda iluminista" pronta a atuar subsidiariamente ante a inércia dos demais poderes. Streck transcreve o seguinte trecho, escrito por Barroso, verbis: "essa matéria [a ADPF tratando do aborto de anencéfalos], o processo legislativo, o processo político majoritário, não consegue produzir uma solução.”

Streck (2013a) chama a atenção para o fato de que ativismo e judicialização são temas que vem despertando, não só no Brasil, um conjunto de pesquisas que buscam a explicação desse fenômeno. A "juristocracia" (ou judiciariocracia), manifestada pelos juízes atualmente (protagonismo judiciário) deve ser considerada frente a relação interinstitucional entre os três poderes e este fenômeno não é uma exclusividade brasileira.

Para o autor, a intensidade da judicialização da política (ou de outras dimensões das relações sociais) é a contradição secundária do problema. Afirma que a grande questão não é o "quanto de judicialização", mas "como as questões 
judicializadas" devem ser decididas. O protagonismo judicial aponta para o perigo que o ativismo judicial representa para a representação política, até porque, como afirma, uma ofensa à Constituição por parte do Poder Judiciário sempre é mais grave do que qualquer outra desferida por qualquer dos outros Poderes, porque é ao Judiciário que cabe sua guarda. O autor admite haver um excesso de ativismo, e afirma que não há um "ativismo adequado ou necessário".

Streck (2013a) insiste que o ativismo não quer dizer se o STF julga de acordo com o parlamento ou de acordo com o governo, e uma simples declaração de uma inconstitucionalidade não significa ter havido ativismo ou não ativismo. O controle de constitucionalidade é justamente a função precípua e democrática de uma corte constitucional. Para o autor, judicializar a política pode não ser exatamente o mesmo que praticar ativismos. A judicialização é contingencial. Ela não é um mal em si. O problema é o ativismo que é comportamental. No Brasil, ambos - ativismo e judicialização - são tratados de forma idêntica.

Um exemplo, para o jurista, seria quando o STF decidiu que, no artigo 366 do CPP, a prova será considerada à luz do arbítrio do juiz ao decidir. Nesse caso, explica o autor, o juiz está não somente praticando ativismo com a institucionalização da discricionariedade judicial (ponto importante para aferir o grau de ativismo e da judicialização) como também está "legislando".

Para o autor, a discussão sobre a judicialização não deve ficar restrita à atuação (ou crítica à atuação) do STF. Analisando a questão da judicialização da saúde e reconhecendo o fato de que juízes de todo o país decidem a respeito, o autor chama a tenção para o fato de que várias unidades da federação gastam mais em pagamento de ações judiciais sobre o acesso à saúde e remédios do que nos próprios orçamentos, negando validade a um dispositivo da Constituição originária, que trata da relação direta entre os poderes de Estado.

Streck afirma que a doutrina, quando diz que está aplicando "a tal da ponderação", de fato, não está nem perto do que dizia seu idealizador (Alexy):

(...) e a doutrina pouco ou nada diz a respeito, é porque corremos o risco de fracassar (aliás, há prova maior de ativismo do que o uso da vulgata da tal da ponderação, pedra filosofal da interpretação?). Como falei na Conferência de abertura do Conpedi (Conselho Nacional de Pesquisa e Pós-Graduação), em Curitiba, dia 29 de maio último, fôssemos médicos e estaríamos ignorando coisas mínimas da ciência médica e nossos pacientes estariam morrendo. Assim o é com a doutrina.

Em outro texto, o Streck (2013b) analisa o fato de o STF declarar ou não declarar um ato normativo como inconstitucional, e a relação com o ativismo/judicialização da política. O STF (ou outros tribunais) tendem a declarar a inconstitucionalidade de leis em alto índice e, necessariamente, tal atitude não poderá ser considerada como ativista/judiciopolítica.

Em trabalho sobre número/tipos de ações julgadas pelo STF, observa Streck (2013b), que o número de ADIs seria um termômetro do coeficiente de judicialização. No plano do controle difuso constitucional, a judicialização (ou o ativismo) é muito mais significativo. A judicialização do direito à saúde, por exemplo, passa por poucas ações no Supremo Tribunal Federal (controle concentrado), mas por dezenas de milhares de ações nos fóruns e tribunais da República. Portanto, as ADIs são só a ponta pequeníssima do enorme iceberg, podendo induzir ao erro. Para o autor, um simples mandado de segurança deferido pelo STF em relação ao direito de saúde, por exemplo, determinando que remédios fora da lista do SUS podem ser objeto de determinação judicial já representa um contingente de efeitos colaterais no campo da relação ativismo-judicialização.

Assim, ao analisar a crise institucional, o estudo alude a alguns comentários (por exemplo, de Luís Roberto Barroso), de que estaria havendo esse risco. Entretanto, para o autor não consta que no conjunto das obras jurídicas que criticam o ativismo do Judiciário possa ser encontrada essa afirmação de que o Brasil corre o risco de uma crise institucional. O 
problema, para o autor, está no conceito de ativismo (ou de judicialização) que o estudo utiliza, a cultura jurídica brasileira estaria equivocada porque usaria casos mentirosos para demonstrar um "excesso de ativismo" ou de judicialização.

Para Streck (2013b), a judicialização é contingencial, ela não é um mal em si e ocorre na maioria das democracias. O problema é o ativismo, que, para ele, é a "vulgata da judicialização". Enquanto a judicialização é um problema de (in)competência para prática de determinado ato (políticas públicas, por exemplo), o ativismo é um problema de comportamento, em que o juiz substitui os juízos políticos e morais pelos seus, a partir de sua subjetividade.

Streck (2013b) concorda que os problemas decorrentes do presidencialismo de coalizão se estendem ao Poder Judiciário. Para ele, parece não haver dúvidas de que o STF vem julgando por argumentos de políticas e não por princípios. Cita, por exemplo: os segmentos a favor das cotas raciais que não manifestaram sua vontade política; pelo contrário, se direcionam ao Supremo Tribunal reivindicar sua legitimidade.

A partir do ponto de vista de Streck (2018), existe um mito do bom e do mau ativismo e o Supremo Tribunal Federal, nestes 30 anos, tem praticado uma dose considerável de ativismo. Reitera que não podem ser classificadas de ativistas decisões de controle de constitucionalidade - tarefa precípua da corte. O ativismo é comportamental, espécie de "behaviorismo cognitivo-interpretativo" e diferente da judicialização que, como antes se disse, é contingencial. O ativismo sempre é ruim para a democracia, porque decorre de comportamentos e visões pessoais de juízes e tribunais, como se fosse possível uma linguagem privada, construída à margem da linguagem pública. Já a judicialização pode ser ruim ou pode não ser.

De parte do jurista, deve-se exigir a garantia de direitos sociais, econômicos e culturais. Exigir respeito aos princípios da ordem econômica social-democrata. Levar a Constituição a sério, pois, não é qualquer reforma à Constituição Federal que será compatível com ela mesma ou poderá perder seu caráter normativo e se transformar em mera carta política.

Streck (2018) elenca o efetivo papel que uma Suprema Corte deve exercer, e cita as cortes da Europa, onde a questão volta a ser objeto de debate sempre que direitos fundamentais são colocados em risco, fazendo com que sejam lembrados os tribunais constitucionais. No Brasil, não apenas os direitos fundamentais exigem e exigirão o cumprimento estrito da Constituição. Complementa:

Moralizar o Direito, como faz Barroso, tem a ver com o que de Dworkin, mesmo? Trata-se de (mais) uma subleitura de Dworkin, para quem o Direito, entendido como um ramo da moralidade política, tem uma autonomia própria que pressupõe níveis de institucionalidade, de padrões compartilhados, aspectos que afastam peremptoriamente qualquer tipo de moralização subjetivista. Por que é tão difícil entender isso?

Segundo Streck (2018), o professor e ministro Barroso defende um ativismo "soft", e cujas decisões são muitas vezes, ativistas "de verdade":

A responsabilidade política que a prática jurídica impõe exige coerência: defender um suposto sentido 'original', articulado pelos pais fundadores, é, muitas vezes, ignorar expressamente a autoridade do texto-enquanto-texto. A partir de meu olhar hermenêutico, concordo com Dworkin e afirma que o originalismo é, muitas vezes, um desrespeito à tradição em seu sentido mais autêntico.

Sintetiza o autor que o problema disso tudo está em que, quando aceitamos o ativismo jurídico como verdadeiro, quando a discussão jurídica não é mais jurídica, mas "consequencialista-pragmática-moralista-econômica", e torna-se aceitável e não surpreendente.

Em outro texto, Streck (2020a) defende o juízo de garantias como necessário à imparcialidade e para preservar as garantias constitucionais-processuais. E, segundo seu entendimento, atrasar a decisão que a instala se enquadra no conceito de 
ativismo, ao contrário de algumas teses e estatísticas que circulam misturando conceitos de judicialização e ativismo - que o autor vem criticando.

Quanto à questão da nomeação diretor-geral da PF, anterior chefe da Abin, ocorrido em 2020, o autor questiona:

Afinal, quem pode ser ministro ou quem pode ocupar um cargo que é de livre nomeação do presidente da República? Quem pode dizer que um nome é bom ou é ruim?

Afirma que a questão é o aspecto simbólico da interferência do Judiciário em assuntos que não são de sua alçada. Streck (2020b) frisa que dentre as atribuições do presidente da República previstas na Constituição do Brasil, uma delas é a de nomear o diretor da Polícia Federal. $\mathrm{O}$ autor conclui que a decisão não se mostra adequada. Invade prerrogativa de outro poder e coloca as escolhas do Poder Executiva sob censura prévia. Situações que ocorreram também em governos anteriores. Para ele, legitimar uma decisão ativista porque concordamos com a racionalidade moral ali pressuposta nada mais é do que legitimar que o Direito possa ser filtrado pela moral. "E se aceitarmos que o Direito seja filtrado pela moral, indago: quem vai filtrar a moral?"

Eis aí, para o autor, a diferença entre Direito e moral. Entre a racionalidade jurídica e os argumentos morais. Ou a moralização do Direito. Não se pode olhar a política como ruim a princípio. Se o presidente erra na nomeação de um servidor, o ônus é dele. É o ônus da política. E, deste modo, não há previsão constitucional que autoriza o judiciário barrar esse tipo de ato administrativo sob argumentos subjetivos.

\section{A Verdadeira Diferença entre Ativismo Judicial e Judicialização de Políticas Públicas}

No Brasil, segundo Abboud (1014), o ativismo é entendido como desapego à legalidade vigente a pretexto de fazer prevalecer a justiça da decisão e pode ser visualizado em diversas manifestações doutrinário-forenses, tais como: relativização da coisa julgada, atribuição de efeito vinculante para decisões e súmulas inconstitucionais, objetivação do controle difuso de constitucionalidade, dentre outros. Ou seja, para ele o ativismo não possui ideologia ou orientação político predefinida e o que o caracteriza é a substituição da legalidade vigente do texto constitucional pelo senso de justiça e pelas convicções pessoais do magistrado da ocasião. E complementa:

Em verdade, no Brasil, o termo ativismo tem sido utilizado para justificar inúmeras decisões que, perante uma análise um pouco mais aprofundada, facilmente seriam identificadas como inconstitucionais ou ilegais.

Vieira (2008) pondera que a Constituição Federal Brasileira de 1988 é "ambiciosa" e faz uma série de promessas sociais, o que enseja uma explosão de litigiosidade constitucional. Diante disso, a liberdade do agente político diminui e muitas matérias acabam sendo decididas no Supremo Tribunal Federal, de forma que o STF passa a exercer a função de "criação" do direito que é "reservada a outro órgão representativo".

Nesse sentido, Cittadino (2004) esclarece que no Brasil se observa uma ampliação do controle normativo do Poder Judiciário, favorecida pela Constituição de 1988, que, ao incorporar direitos e princípios fundamentais, configurar um Estado e Democrático de Direito e estabelecer princípios e fundamentos do Estado, viabiliza uma ação judicial que recorre a procedimentos interpretativos de legitimação de aspirações sociais.

Por outro lado, Alvim, Thamay e Granado (2014), no livro "Processo Constitucional", esclarecem que há uma diferença entre judicialização e o ativismo judicial:

Ativismo judicial é caracterizado pela postura mais ativa do PJ, que busca, diante da falta de solução legislativa adequada para determinado caso, criar soluções para a implementação, sobretudo, de políticas públicas (...) A 
Judicialização decorre do modelo constitucional que se adotou, e não um exercício deliberado de vontade política. Se uma norma constitucional permite que dela se deduza uma pretensão, subjetiva ou objetiva, ao juiz cabe dela conhecer, decidindo a matéria. $\mathrm{O}$ ativismo é uma atitude, a escolha de um modo específico e proativo de interpretar a Constituição. A ideia do ativismo está associada a uma manifestação ampla e intensa do Judiciário na concretização de valores e fins institucionais. O ativismo, na visão de Lenio Streck, está baseado no catálogo interminável de princípios e cada ativista inventa um princípio novo. O STF em muitas decisões (exemplo ADPF 45) adota uma postura ativista para concretizar direitos fundamentais previstos na constituição federal, sendo necessária a participação do Poder judiciário como realizador e implementador das políticas públicas descumpridas (pp. 183-193).

Mendes e Abboud (2019), esclarecem que ativismo é uma postura discricionária de ingerência do Poder Judiciário no Poder Legislativo não se confundindo com “controle de constitucionalidade”, "e que a atuação contramajoritária, a afirmação de direitos fundamentais, exercidas por meio da judicial review, são essenciais numa democracia tão frágil quanto a brasileira". Os autores criticam o ativismo e defendem que o texto normativo possui um sentido próprio e que para a democracia é fundamental traçar-se teorias da decisão não ativistas aptas a impedir decisões subjetivas e dependentes dos valores individuais de cada intérprete, cabendo a cada juiz assegurar as regras do jogo previamente estabelecidas.

Ativismo judicial e Judicialização de políticas públicas não se confundem.

\section{As Regras e o Contexto do Jogo Democrático}

Abboud (2020) lembra que "democracia é a forma de governo que reserva ao povo a titularidade e o exercício do poder político. Opõe-se, portanto, à monarquia - 'governo de um só' - e à aristocracia - 'governo de alguns' -, nos termos do que leciona a tradição geral que, nos primórdios, inaugurou um regime democrático direto e restritivo.” E que, portanto, “exige participação popular direta e indireta, a se realizar de acordo com a regra da maioria. A regra da maioria é ínsita e fundamental a todo regime democrático".

Assim, se democracia é um jogo, cujas regras são fixadas pela maioria e os "players" são "o povo", em que medida o Supremo Tribunal Federal tem "poder” para exercer uma função contramajoritária?

Abboud (2020) afirma que é preciso proteger a democracia dela mesma, afastando a tirania da maioria contra a minoria, tendo sido propostas por Hans Kelsen duas premissas teóricas para tanto: o princípio democrático da liberdade e a não associação da liberdade à vontade da maioria. E esclarece a proposta de Kelsen de uma democracia em parceria:

A democracia em parceria é aquela em que cada integrante da sociedade é considerado full partner (parceiro integral) do projeto democrático, uma vez que é componente do próprio projeto político. Cuida-se de modelo que repele a supressão de direitos de uma minoria apenas porque é esta a determinação da vontade majoritária. Para construção da democracia em parceria são essenciais mecanismos contramajoritários para a proteção de direitos e de segmentos da sociedade. O controle de constitucionalidade é um exemplo perfeito, pois se destina a nadificar a lei, produzida pelos representantes do povo, sempre que violar a esfera de direitos fundamentais de qualquer dos jurisdicionados (p.03).

Assim, nas regras para o jogo democrático, o STF exerce o poder das minorias para evitar a tirania das maiorias.

Outra regra do jogo democrático é exercida pela presença dos direitos fundamentais na Constituição Federal, pois a função destes deve ser a de proteger a minoria no governo da maioria. E, nesse sentido, o controle de constitucionalidade seria um mecanismo do jogo democrático.

Abboud ainda lembra que "ao escrever sobre democracia, Norberto Bobbio aduziu que, nada obstante possamos defini-la das maneiras mais diversas, todas as concepções precisam incluir as noções de visibilidade ou transparência do poder. A imposição de transparência está diretamente relacionada à noção de accountability, i.e., prestação de contas.” E sustenta que: 
É um regime cujo potencial democrático se esgota no exercício do voto. O carisma como elemento forte da política é característico das democracias delegativas. Representação e accountability conformam a dimensão republicana da democracia, consubstanciada em uma cuidadosa distinção entre o espaço público e privado em relação aos ocupantes do cargo público (p.04).

Assim, o autor sugere duas regras para a o exercício justo da democracia: métodos de autocontenção e respeito aos adversários legítimos. ${ }^{1}$

Sobre esse aspecto da transparência como requisito para uma democracia possível, Han, Byung-Chul (2017) pondera que a transparência, na realidade, demonstra uma falta de credibilidade da sociedade com ela mesma que torna exigível uma constante prestação de contas como forma de controle constante, e, ao dissertar sobre a exposição exacerbada nas redes digitais e o clamor por transparência, defende que:

Essa supervisão total degrada a transparent society a uma sociedade desumana, na qual todos controlam todos. Transparência é um estado no qual se elimina todo e qualquer não saber, pois onde impera a transparência já não há espaço para a confiança." "A transparência destrói a confiança." "Por isso, a sociedade da transparência é uma sociedade da desconfiança e da suspeita, que, em virtude do desaparecimento da confiança, agarra-se ao controle; A intensa exigência por transparência aponta precisamente para o fato de que o fundamento moral da sociedade se tornou ágil, que os valores morais da honestidade e sinceridade estão perdendo cada vez mais importância (pp. 105116).

Assim, ao contrário da prestação de contas representar uma garantia ao jogo democrático, ela apenas reforça a fragilidade das Instituições e a vulnerabilidade dos partners.

Abboud (2020) ainda trata da crise de representatividade como motor da autocracia (governo de alguns) e ensina que "a globalização da economia e da comunicação, não bastasse prejudicar as economias nacionais, limitou a capacidade do Estado de responder internamente a problemas que, na sua gênese, são globais (e.g. crises financeiras, violação aos direitos humanos)." E continua:

O indivíduo, que teme a globalização, busca refúgio na nação. Afrontado pela imigração e pelo multiculturalismo, fortemente consorciados à globalização, o cidadão atende ao chamamento identitário; descrente nas figuras políticas que "estão aí", persegue um novo representante, no qual possa se fiar. Movidos pelo medo, a mais poderosa das emoções, os setores mais vulneráveis da sociedade se aglutinam em torno dos agentes que, despudoradamente, destilam discurso xenófobo e racista, recorrem à força estatal como método de resolução de todos os problemas, simplificam a crise mediante polarizações, e se levantam contra "a corrupção generalizada", de que, não raro, tomam (ou tomaram) parte.

Nesse contexto, Harari (2018) pondera que "problemas globais exigem respostas globais". Porém, não é o que se nota no Brasil. Abboud (2020) aponta para uma crise institucional e de representatividade, o que leva as pessoas acreditarem e

\footnotetext{
${ }^{1}$ No Brasil o Presidente da República faz verdadeiro "ativismo às avessas" e contribui para a crise institucional ao legislar por Medidas Provisórias durante a pandemia do COVID-19, desrespeitando seus adversários e os limites de sua atuação administrativa. Na recente MP 966/2020 (dos atos de responsabilidade de agentes públicos) o Presidente da República legislou revogando, no mínimo, dispositivo do Código Civil para afastar o "nexo de causalidade" dos atos de responsabilidade dos representantes do Poder Executivo em estado de calamidade, in verbis: “Art. $1^{\circ}$ Os agentes públicos somente poderão ser responsabilizados nas esferas civil e administrativa se agirem ou se omitirem com dolo ou erro grosseiro pela prática de atos relacionados, direta ou indiretamente, com as medidas de: I - enfrentamento da emergência de saúde pública decorrente da pandemia da covid-19; e II - combate aos efeitos econômicos e sociais decorrentes da pandemia da covid-19. § $1^{\circ} \mathrm{A}$ responsabilização pela opinião técnica não se estenderá de forma automática ao decisor que a houver adotado como fundamento de decidir e somente se configurará: I - se estiverem presentes elementos suficientes para o decisor aferir o dolo ou o erro grosseiro da opinião técnica; ou II - se houver conluio entre os agentes. $\$ 2^{\circ} \mathrm{O}$ mero nexo de causalidade entre a conduta e o resultado danoso não implica responsabilização do agente público.”. (http://www.planalto.gov.br/ccivil_03/_Ato2019-2022/2020/Mpv/mpv966.htm). Sobre legalismo autocrático, cf. o que escrevemos no item ..., supra.
} 
reforçarem os Poderes dos políticos que representam o papel do "salvador da pátria", personagens que prometem "transparência" ao povo com soluções locais e isoladas.

Abboud (2020) alerta, então, que "os novos políticos se legitimam pela lógica da oposição (afinal, são a negação de 'tudo o que está aí'). Em resumo, a crise de identidade abre caminho para o surgimento de candidatos antiestablishment, que se elevam por meio da negativa geral de tudo que está posto, o que implica, inclusive, a negação de valores outrora considerados positivos (i.e., inclusão social, solidariedade) e afirmação daquilo que anteriormente era explicitamente condenável (i.e. xenofobia, racismo, machismo, etc.)."

Harari (2018) então ensina que o melhor resultado que o terror criou, sem, contudo, objetivá-lo, foi o próprio medo generalizado sem fundamento e desproporcional com outros problemas evidentes, o que faz com as que os governantes exerçam seus poderes sobre seus "súditos" baseados no "medo do terror" e na falsa "promessa de segurança" e segue:

Para aliviar esses temores, o Estado é levado a responder ao teatro do terror com o seu próprio teatro da segurança. A resposta mais eficiente ao terrorismo poderia ser uma boa inteligência e ação clandestina contra as redes financeiras que abastecem o terror. Mas isso não é algo que os cidadãos possam ver na televisão. Os cidadãos viram o drama terrorista do World Trade Center desmoronando. O Estado sente-se compelido a encenar um contradrama igualmente espetacular, com ainda mais fogo e fumaça. Assim, em vez de agir silenciosa e eficientemente, o Estado desencadeia uma poderosa tempestade, que muitas vezes realiza os mais acalentados sonhos dos terroristas. (p. 209).

Abboud (2020) conclui, então, que "uma sociedade polarizada" contribui para uma política autoritária e o consequente enfraquecimento das Instituições, abrindo espaço para um jogo antidemocrático, e prossegue:

Encontrar um common ground é condição de possibilidade para a resolução sadia das discordâncias. É o common ground que permite a argumentação genuína entre interlocutores. (...) Juntos, o valor intrínseco e a responsabilidade pessoal conformam as bases e condições da dignidade humana; são, grosso modo, dimensões da dignidade humana, que, no plano político, travestem-se daquilo que conhecemos como equidade e liberdade (p.10).

A pesquisa parece demonstrar que é por meio do "terror" que o governante exerce seu "poder" de representação da massa que se vê acuada e submissa. Nesse sentido, tem campo fértil decisões ativistas proferidas pelo Poder Judiciário na luta com os demais Poderes. E assim, diante de uma crise institucional marcada pela polarização, propostas de soluções locais e empoderados pelo terror que propagam abrem espaço para decisões ativistas (e ilegítimas) do Poder Judiciário, sendo necessário encontrar um "espaço comum" com regras claras e predefinidas, isentas de uma atitude pautada na subjetividade de cada intérprete do Poder Judiciário, tornando justo o jogo democrático.

\section{Decisões Judiciais Durante a Pandemia de COVID-19 e a Crise Democrática Brasileira}

A pesquisa preocupou-se em fazer um levantamento de algumas decisões recentes proferidas pelos Tribunais durante a pandemia para demonstrar o impacto da fragilidade das Instituições, e o exercício do ativismo judicial (às vezes "ativismo às avessas do Poder Executivo") no contexto do jogo democrático brasileiro.

\subsection{ADPF 668 - campanha publicitária presidencial “O Brasil não pode parar”. 2}

Trata-se de ação proposta pela Confederação Nacional dos Trabalhadores Metalúrgicos em face do Presidente da República buscando seja obstada a campanha publicitária “O Brasil não pode parar”. Seguindo as orientações e protocolos da OMS, acertadamente o governo federal, com o aval do Poder Legislativo, decretou "Estado de emergência em saúde pública",

2 Disponível em: http://portal.stf.jus.br/processos/detalhe.asp?incidente=5884082. 
suspendendo a maioria das atividades públicas e privadas, o que também ocorreu nos demais poderes da República, nos Estados da Federação e na totalidade dos Municípios. Posteriormente, o governo federal lançou a campanha "O BR não pode parar". "A referida campanha publicitária, diga-se, a custa do erário, no valor de $\mathrm{R} \$ 4.897 .855,00$ (quatro milhões, oitocentos e noventa e sete mil, oitocentos e cinquenta e cinco reais), foi dispensada de licitação por ter sido classificada "emergencial pela SECON, além de ofender direitos humanos fundamentais" (a vida e a saúde de milhares de brasileiros).

A arguição de descumprimento de preceito fundamental se fundamentou no artigo 196 da CF nos seguintes termos: “Aqui não se cogita de intervenção no processo decisório do executivo, mas de proteção da Constituição e dos Princípios nela contidos, em razão de absurdo expediente publicitário a custa do erário público, simultaneamente a uma inominável tragédia de incalculáveis proporções para a vida do povo brasileiro, e com bases inteiramente controversas, (...)".

O Ministro Luís Roberto Barroso deferiu a medida liminar para impedir a circulação da campanha com o seguinte fundamento:

É igualmente importante ter em conta que não se trata aqui de uma decisão política do Presidente da República acerca de como conduzir o país durante a pandemia. Haveria uma decisão política, no caso em exame, se a autoridade eleita estivesse diante de duas ou mais medidas aptas a produzir o mesmo resultado: o bem estar da população, e optasse legitimamente por uma delas. Não é o caso. A supressão das medidas de distanciamento social, como informa a ciência, não produzirá resultado favorável à proteção da vida e da saúde da população. Não se trata de questão ideológica. Trata-se de questão técnica. E o Supremo Tribunal Federal tem o dever constitucional de tutelar os direitos fundamentais à vida, à saúde e à informação de todos os brasileiros.

Trata-se de um caso em que há um "ativismo às avessas" do Governo Federal, tendo o Poder Judiciário feito uma interpretação conforme a Constituição Federal.

\subsection{ADI 6424, ADI 6421, ADI 6422, ADI 6425, ADI 6427, ADI 6431 sobre a MP 966 que flexibiliza a responsabilização} de agentes públicos por erros ou omissões na tomada de decisões para o combate à pandemia da Covid-19 - decisão liminar do Ministro Barroso

O Ministro Luís Roberto Barroso entende que não há inconstitucionalidade da norma e deu uma interpretação conforme a constituição. Segue a decisão:

Após o voto do Ministro Roberto Barroso (Relator), que: a) deferia parcialmente a cautelar para conferir interpretação conforme à Constituição ao art. $2^{\circ}$ da MP 966/2020, no sentido de estabelecer que, na caracterização de erro grosseiro, deve-se levar em consideração a observância, pelas autoridades: (i) de standards, normas e critérios científicos e técnicos, com especial destaque para as orientações da Organização Mundial de Saúde; bem como (ii) dos princípios constitucionais da precaução e da prevenção; b) conferia, ainda, interpretação conforme à Constituição ao art. $1^{\circ}$, § $1^{\circ}$, da MP 966/2020, para explicitar que, para os fins de tal dispositivo, a autoridade à qual compete a decisão deve exigir que a opinião técnica trate expressamente: (i) das normas e critérios científicos e técnicos aplicáveis à matéria, tal como estabelecidos por organizações e entidades médicas e sanitárias, reconhecidas nacional e internacionalmente; (ii) da observância dos princípios constitucionais da precaução e da prevenção; e c) firmava as seguintes teses: "1. Configura erro grosseiro o ato administrativo que ensejar violação ao direito à vida, à saúde ou ao meio ambiente equilibrado, por inobservância: (i) de normas e critérios científicos e técnicos; ou (ii) dos princípios constitucionais da precaução e da prevenção. 2. A autoridade a quem compete decidir deve exigir que as opiniões técnicas em que baseará sua decisão tratem expressamente: (i) das normas e critérios científicos e técnicos aplicáveis à matéria, tal como estabelecidos por organizações e entidades médicas e sanitárias, internacional e nacionalmente reconhecidas; e (ii) da observância dos princípios constitucionais da precaução e da prevenção, sob pena de se tornarem corresponsáveis por eventuais violações a direitos", o julgamento foi suspenso. Falaram: pelo requerente, o Dr. André Maimoni; e, pelo interessado, o Ministro José Levi Mello do Amaral Júnior, Advogado-Geral da União. Ausente, justificadamente, o Ministro Celso de Mello. Presidência do Ministro Dias Toffoli. Plenário, 20.05.2020 (Sessão realizada inteiramente por videoconferência - Resolução $672 / 2020 / \mathrm{STF})$.” http://portal.stf.jus.br/processos/detalhe.asp?incidente=5915876. 
A MP 966 prevê que os agentes públicos somente serão responsabilizados nas esferas civil e administrativa se agirem ou se omitirem com dolo ou erro grosseiro nas medidas de combate à pandemia. As ações foram ajuizadas para discutir a inconstitucionalidade formal e material da medida provisória; porém, na decisão liminar o Ministro Barroso, para fundamentar seu voto, adentrou na discussão sobre a possibilidade de adoção de medidas de isolamento social e uso de medicamento sem experimentação científica. Por maioria de votos foi deferida liminar nos seguintes termos:

O Tribunal, por maioria, analisou a medida cautelar, vencido, preliminarmente, o Ministro Marco Aurélio, que entendia pela inadequação da ação direta. Na sequência, por maioria, deferiu parcialmente a cautelar para: a) conferir interpretação conforme à Constituição ao art. $2^{\circ}$ da MP 966/2020, no sentido de estabelecer que, na caracterização de erro grosseiro, deve-se levar em consideração a observância, pelas autoridades: (i) de standards, normas e critérios científicos e técnicos, tal como estabelecidos por organizações e entidades internacional e nacionalmente conhecidas; bem como (ii) dos princípios constitucionais da precaução e da prevenção; e b) conferir, ainda, interpretação conforme à Constituição ao art. $1^{\circ}$ da MP 966/2020, para explicitar que, para os fins de tal dispositivo, a autoridade à qual compete a decisão deve exigir que a opinião técnica trate expressamente: (i) das normas e critérios científicos e técnicos aplicáveis à matéria, tal como estabelecidos por org (...).

Parece-nos que a medida provisória peca ao tentar afastar a culpa e o nexo de causalidade como pressupostos da responsabilidade civil por meio de medida provisória, realizando verdadeira "blindagem" dos atos de agentes públicos como colocado pelos patronos das referidas ações. Há uma verdadeira atuação ativista às avessas do Poder Executivo e uma confusão conceitual do Poder Judiciário na medida em que, ao invés de julgar a inconstitucionalidade da medida provisória passa a discutir as políticas que devem ser adotadas pelo Poder Executivo no enfrentamento à pandemia do COVID-19 com fundamento em "valores" pessoais do intérprete que usa a Constituição Federal para legitimar suas decisões.

\subsection{Sobre o lockdown - decisão pioneira do Estado do Maranhão}

A Vara de Interesses Difusos e Coletivos da Comarca da Ilha de São Luís ordenou, na quinta-feira (30/4), que o estado do Maranhão e a cidade determinem o bloqueio total de atividades (lockdown) na capital. Como $100 \%$ dos leitos de unidade de terapia intensiva (UTI) da rede pública de saúde em São Luís estão ocupados por pacientes com Covid-19. O Ministério Público estadual, na ação civil pública n. 0813507-41.2020.8.10.0001, afirmou na ação que, mesmo com os leitos a serem criados pelos hospitais de campanha, o sistema de saúde pode entrar em colapso se não forem tomadas medidas de prevenção mais drásticas. Em sua decisão, o juiz disse que há probabilidade do direito e risco da demora que justificam a concessão da tutela de urgência, uma que a saúde dos maranhenses corre risco. ${ }^{3}$

\subsection{Ação civil Pública do MPSP em face da Fazenda Pública do Estado de São Paulo}

O objetivo da ação era determinar que a Fazenda do Estado de SP feche as fronteiras de cidades litorâneas durante o "feriado" antecipado decretado pelo município de São Paulo. ${ }^{4}$

Em primeiro grau foi deferido o pedido liminar e determinou o fechamento das fronteiras. Em grau de recurso interposto pela Fazenda do Estado de São Paulo o TJSP reformou a decisão sob o fundamento de que a competência em questão de saúde e, portanto, para atos administrativos é do Estado e, de forma suplementar, dos municípios. A decisão liminar além de "invadir" a competência do Estado de São Paulo judicializou uma política pública que caberia somente ao Poder Executivo e não ao Poder Judiciário.

Nesse sentido a decisão esclareceu:

\footnotetext{
${ }^{3}$ Disponível em https://www.conjur.com.br/d1/justica-ordena-lockdown-maranhao-sao.pdf.

${ }^{4}$ Disponível em file://C:/Users/Arquivos/Downloads/decisa\%CC\%83o\%20judicial\%20urgente1.pdf e https://www.conjur.com.br/dl/tj-sp-suspende-proibicaoacesso.pdf .
} 
A gravidade da pandemia recomenda seja a menor possível a judicialização da matéria, porque intervenção pontual nas políticas públicas compromete a organização dos atos da Administração. Nesse sentido, ao Poder Judiciário parece lícito intervir apenas e tão-somente em situações que evidenciem omissão das autoridades públicas competentes, capaz de colocar em risco grave e iminente os direitos dos jurisdicionados. O risco de lesão à ordem pública se prende também ao caráter satisfativo da liminar concedida pelo Juízo da comarca de Itanhaém, capaz de impactar diretamente no planejamento da Administração. A esse acresço o fato de que o ato judicial em análise introduziu modificações nas políticas públicas, âmbito de atuação primordialmente reservado ao Poder Executivo, de forma a dificultar o adequado exercício das funções típicas da Administração e a comprometer a condução coordenada das ações necessárias à mitigação dos danos provocados pela COVID-19. (...) Neste cenário de nenhuma omissão, insisto, decisões isoladas em atendimento a parte da população, tem o potencial de promover a desorganização administrativa, obstaculizando a evolução e o pronto combate à pandemia.

\section{Considerações Finais}

O Direito é um jogo? Se é um jogo, quais são suas regras? A verdade e a moral são regras do jogo do Direito?

O trabalho parte da premissa de que a moral não é regra do jogo de Direito, mas sim a verdade, o julgador precisa ser um sujeito "parresiástico".

No desenvolvimento do trabalho, preocupamo-nos em estudar o fenômeno do ativismo judicial, as primeiras percepções históricas e discussões jurídicas e, seu impacto na democracia brasileira frente os atuais acontecimentos. Para tanto, investigou-se o posicionamento de Luís Roberto Barroso, ministro do STF, fazendo-se um contraponto com o entendimento de Lenio Luiz Streck sobre o tema. Observou-se que, enquanto Barroso admite a pratica de ativismo judicial em determinadas circunstâncias, STRECK se opõe a essa prática.

Apresentamos, também, a diferenciação de judicialização de políticas públicas e seu reflexo nas recentes decisões proferidas durante o período da pandemia causada pelo COVID-19.

Observamos a existência de crises nas instituições democráticas devido aos excessos de ativismos, fenômeno no qual a moral e o subjetivismo de cada intérprete balizam as decisões judiciais, tornando injusto o jogo do Direito na medida em que não se joga com as regras democráticas previamente estabelecidas.

Usar de tais estratégias é um caminho que dificulta diminuir a polarização político-ideológica pela qual estamos passando. De modo que se perpetuam as crises, seja a econômica, social ou a sanitária da COVID-19, e as que virão em decorrência dessas, de cuja extensão ainda não se tem noção.

\section{Referências}

Abboud, G. (2020). Democracia e Forbearance: Reflexões acerca das regras implícitas no jogo democrático. Revista de Processo, 299,17 - 40.

Abboud, G. (2014). Discricionariedade Administrativa e Judicial. O Ato administrativo e a Decisão Judicial: Editora Revista dos Tribunais.

Abboud, G., Carcnio H. G., \& Oliveira, R. T. (2015). Introdução à Teoria e à Filosofia do Direito. (3a ed): Revista dos Tribunais.

Alvim, E. A., Thamay, R. F., \& Granado, D. W. (2014). Processo Constitucional: Editora Revista dos Tribunais.

Barroso, L. R. (2005). Neoconstitucionalismo e Constitucionalização do Direito (O triunfo tardio do direito constitucional no Brasil). Revista de Direito Administrativo, 240, 1-42. [http://bibliotecadigital.fgv.br/ojs/index.php/rda/article/view/43618].

Barroso, L. R. (2012). Judicialização, Ativismo Judicial e Legitimidade Democrática. Revista [Syn]Thesis, 5 (1), p.23-32.

Cittadino, G. (2004). Poder Judiciário, ativismo judiciário e democracia. Revista Alceu, 5, 105-113.

Eco, U. (2018). Interpretação e Superinterpretação. (4a ed.): Martins Fontes.

Eco, U. (2004). Os Limites da Interpretação. (2a ed.): Editora Perspectiva.

Focault, M. (2017). A coragem da verdade: o governo de si e dos outros: Martins Fontes.

Han, B-C. (2017). Sociedade da Transparência: Editora Vozes.

Harari, Y. N. (2018). 21 Lições para o século 21: Editora Companhia das Letras. 
Research, Society and Development, v. 10, n. 3, e9010313009, 2021

(CC BY 4.0) | ISSN 2525-3409 | DOI: http://dx.doi.org/10.33448/rsd-v10i3.13009

Huizinga, J. (2012). Homo Ludens: o jogo como elemento da cultura: Editora Perspectiva.

Medina, J. M. G. (2020). Constituição Federal Comentada. (5a ed.): Revista dos tribunais.

Mendes, G. F., \& Abboud, G. (2019). Ativismo Judicial: Notas Introdutória a uma polêmica contemporânea. Revista dos Tribunais, $1008,43-54$.

Silva, J. A. (2013). Parecer. Proposta de Emenda Constitucional 33/2011 "Indicação 017/2013". Revista do Instituto dos Advogados do Brasil (digital), Ano IV, (17), 1-12.

Streck, L. L. (2010). O que é isto - decido conforme minha consciência? 2a. Edição revisada e ampliada: Editora Livraria do Advogado.

Streck, L. L. (2013a). Ativismo judicial existe ou é imaginação de alguns? Revista eletrônica Conjur. [https://www.conjur.com.br/2013-jun-13/sensoincomum-ativismo-existe-ou-imaginacao-alguns].

Streck, L. L. (2013b). Ativismo judicial em números. Revista eletrônica Conjur. [https://www.conjur.com.br/2013-out-26/observatorio-constitucional-istoativismo-judicial-numeros].

Streck, L. L. (2018a). O motim hermenêutico e os mitos do bom e mau ativismo. Revista eletrônica Conjur. [https://www.conjur.com.br/2018-dez-27/sensoincomum-motim-hermeneutico-mitos-bom-mau-ativismo].

Streck, L. L. (2018b). O futuro do STF: na retranca como diz Toffoli ou no ataque. Revista eletrônica Conjur. [https://www.conjur.com.br/2018-dez-06/sensoincomum-futuro-stf-retranca-toffoli-ou-ataque].

Streck, L. L. (2020a). Ativismo judicial e a vitória de Pirro no JG na decisão de Fux. Revista eletrônica Conjur. [https://www.conjur.com.br/2020-jan27/streck-ativismo-judicial-vitoria-pirro-decisao-fux].

Streck, L. L. (2020b). Judiciário decide quem pode ser ministro e diretor geral da PF? Revista eletrônica Conjur. [https://www.conjur.com.br/2020-abr29/streck-judiciario-decide-quem-ministro-ou-diretor-pf].

Vieira, O. V. (2008). Supremocracia: Revista de Direito GV. 441 a 459. 